УДК $811.161 .2 ’ 161.2$

DOI: $10.31471 / 2304-7402-2019-3(55)-231-236$

\title{
TEACHING OF TALK VERSUS LANGUAGE TEACHING IN THE EFL CLASSROOM
}

\section{O. M. Sernyak}

Ternopil Volodymyr Hnatiuk National Pedagogical University; e-mail: oks_sern@ukr.net

The article analyzes some aspects of the communicative approach to teaching EFL with the emphasis on teaching of talk versus language teaching in the EFL classroom.

It has been revealed that traditional approach to teaching EFL actually separates teaching of foreign language from teaching practical speech. As far as talkers learn to talk by being exposed to communication practices during talking exchanges, it would be more successful to teach a foreign language in the process of actual exchanges of talk that allows participants to coordinate their turn taking in communication with others. The individual must be treated as a talker or participant in a foreign community not as a learner in the classroom. EFL teaching should be based not on teaching language but on teaching of spontaneous talk.

There has been investigated the basic difference between teaching language and teaching of talk. While the unit of language is the sentence, the unit of talk is the exchange. It has been proved that it is rational that teaching verbal fluency in English should not depend on pedagogical units such as 'the sentence', 'the utterance' or 'the structural pattern' but actual speech exchanges between the communicators.

There has been demonstrated that transactional methods designate the orientation towards teaching talk through particular actual exchanges. The pedagogic effort of teaching talk involves exposing the student to social situations in which he is being treated as a talker or a social participant rather than a learner or a participant of a simulated conversation.

Key words: communicative approach to teaching EFL, teaching of spontaneous talk, talking exchanges, contextualized response, transactional exchange.

Foreign language acquisition has always been very complex. The problem lays in the fact that there is frequent lament among many former foreign language learners across many cultures that they never really learned the languages they studied even though they spent several years in the classroom. This common complaint leads to reassessment of the theories and methods popular during the last twenty or thirty years.

Several theoretical concepts are currently under consideration by linguists and methodologists attempting to determine what direction we should

ISSN 2304-7402. Прикарпатський вісник НТШ. Слово. - 2019. - № 3(55). 
take to be effective foreign language teachers who are looking for ways of enhancing communicative skills of their students.

The goal of foreign language acquisition has always been meaningful communication when learners gain the ability to communicate in the target language. Beginning with Hymes' distinguishing communicative competence from linguistic knowledge we have had a lot of research and studies conducted by foreign scholars which develop the communicative approach to language teaching (Bren, Candlin, Cummins, Moskowitz, Nation, Savignon, Scarcella, Slavin, Widdowson).

Representatives of Ukrainian methodology of foreign language teaching (V. Buhbinder, N. Gez, M. Lahovytsky, A. Myroliubov, S. Nikolayeva, N. Skliarenko, O. Vyshnevsky) have contributed a lot to our knowledge of the aspects of language acquisition.

Theoretical models constructed by applied linguists were followed by more practical but definitely related works written by classroom teachers which have proved that language classes doing communicatively-oriented activities achieve higher levels than classes using audio-lingual approach (R. Arends, P. Nation, J. Rubin, O. Pometun, L. Pyrozhenko).

The purpose of this article is to discuss some features of the communicative approach to teaching EFL with the emphasis on teaching of talk versus language teaching in the EFL classroom which presupposes meaningful spontaneous interaction of learners in the process of learning a foreign language.

The paper will demonstrate some ways of implementation of interactive methods in teaching of conversational English versus language teaching in the EFL classroom.

The scientists (C. Richards, T. Rodgers, L. James, B. Gordon, N. Davies) claim that the traditional approach of teaching EFL actually separates teaching the language from teaching of practical speech. The student is taught to accumulate linguistic knowledge and is expected to learn how to use it in speech activity. In G. Atanov's view, the consequence of using the traditional supportive approach to learning EFL is that in reality the students remember a lot of linguistic material not being able to communicate in the target language with others [1].

According to modern pedagogical science, the system of learning should be based on the student who is an active participant of the learning process, and the teacher who is the methodologist and technologist. Y. Mashbits believes the solution of the above mentioned problem is awareness that knowledge can be acquired only in the process of its usage in activities, only by operating it. The accumulation of knowledge takes place simultaneously with the development of ways to deal with it [2].

In foreign language teaching, the requirement today is the implementation of the pedagogical technologies which provide all necessary means to achieve fluency (the transmitting and receiving of ideas and information) and accuracy (using correct grammar, vocabulary, pronunciation).

The practical purpose of teaching a foreign language is preparing students for real communication in a foreign language. Taking the above men-

ISSN 2304-7402. Прикарпатський вісник НТШ. Слово. - 2019. - № 3(55). 
tioned fact into account, modern scholars consider communicative orientation to be the leading methodological principle. This means that learning foreign languages should be based on the entire involvement of students in speech communication [3].

By laws of common sense and practicality individuals learn to speak by being treated as talkers in the social exchange. This expectation follows rationally from the observation that talkers learn to talk by being exposed to communication practices during talking exchanges. Hence, it would be more successful to teach a foreign language in the process of actual exchanges of talk that allows participants to coordinate their turn taking in communication with others.

The individual must be treated as a talker or participant in a foreign community, not as a learner in the classroom. That's why EFL teaching should be based not on teaching the language per se but on teaching of spontaneous talk [7].

It should be noted that spontaneous talk is occasioned through relationship as its situational frame. When treated as learners per se, the students are deprived of relationship, and hence, of the opportunity to evoke talk spontaneously. Hence, the main goal in EFL teaching is not 'correctness', 'fluency' or 'speech naturalness' but spontaneity of talk.

B. Gordon [7] highlights another basic difference between teaching language and teaching of talk is that while the unit of language is the sentence, the unit of talk is the exchange. Thus it is rational that teaching verbal fluency in English should not depend on such hypothetical constructs and pedagogical units as 'the sentence', 'the utterance' or 'the structural pattern' but actual speech exchanges between the communicators.

Systematic observations reveal to the EFL teacher that practicing all kinds of stimulated dialogues in the EFL classroom training or practicing artificial exchanges doesn't lead to the adequate usage of these memorized dialogues in natural communication.

According to L. James, actual exchanges of talk differ from simulated versions because in actual talk, the participants count each other's moves as spontaneous (taken as a sign of relationship between the participants). The participants coordinate each other's behavior in order to become talkers in the social exchange [7].

In simulated talk, the moves of the participants count as role performance or as play acting. In other words, in a classroom, the individual acts as a student who is practicing, not as an individual with identity acting on his own behalf. It is the social relationship which is lacking. It is difficult to imagine that under such conditions it is possible for the student to pick up actual talking exchanges, those that spring spontaneously from involvement in relationship.

Regarding communication as spontaneous interactive language skills, we believe that teaching communication is the most challenging task when the teacher's goal is not teaching the language but spontaneous talk.

In James and Gordon's [7] view, the technique of teaching talk lies in the art of not teaching the language. The so called art of non-teaching the lan-

ISSN 2304-7402. Прикарпатський вісник НТШ. Слово. - 2019. - № 3(55). 
guage in its turn presupposes: a) assumption about what is spontaneous talk; b) techniques for engineering abundant talking exchanges in the classroom.

The scholars $[8,9]$ state that the very basis of spontaneous talk is the involvement. Only if an individual is given a recognized position in a social situation (family, nation, neighborhood, experience, etc.) can that individual behave spontaneously. The nature of spontaneous talk constitutes in the fact that like in all natural social situations in the community we treat each other as fully fledged participants: we have the right to move, to talk, to make requests of others, to deny requests and so on. Spontaneity of talk is predetermined when the individual can act freely and unchecked within the open speaking space.

What does the other person want me to do? What am I to say now? How do I get out of this? These are the immediate issues that confront the participants in an actual exchange: the individual must engineer his way out of a social spot in which he was just put by another participant through a question, an allusion, or a display etc [7].

Spontaneous talk is driven by the emotions, and feelings of the participants. Being a socialized participant the speaker can focus on his imaginings, demonstrating what he believes, knows and figures about some event, state or situation. Understanding the nature of spontaneity in talk enables the EFL teacher to make EFL learning process more effective.

It has been believed of late that the basis of the communicative approach in foreign language teaching has been referred to meaningful interaction between the communicators. Still, it was educator J. Dewey [6], known as 'the father of pragmatism and functionalism' in American education, who argued for switching the focus from interaction to transaction.

It seems the issue is still underestimated in EFL teaching. Let's proceed with the analysis of both terms. While 'language interaction' is 'a mutual or reciprocal action or influence' of the communicators, transaction is associated with talk and is setting occasioned. This shows that the setting for the exchange governs the participant's involvements. While language interaction involves 'contextualized response', talk transaction presupposes 'transactional exchange' - actual exchange rather than a simulated one [7].

In the case of the EFL teaching, transactional methods designate the orientation towards teaching talk through particular actual exchanges rather than a simulated one.

Among the main requirements for teaching talk in the light of the functional approach modern methodologists suggest the following:

1. The language material for the study should reflect the natural usage of language in communication without artificial examples and fictional situations;

2. Mastering the spontaneity presupposes involving different types of communication, including pair and group work.

3 . The linguistic material should clearly highlight the functional aspects. Students should understand the connection between the linguistic materials that are learned with practical speech in a variety of contexts[3].

ISSN 2304-7402. Прикарпатський вісник НТШ. Слово. - 2019. - № 3(55). 
The point is that the teacher has to liberate the students for free and spontaneous speech where the speaker and listener interact in a context that does not allow predictable exchanges.

The creation of social occasions for spontaneous talk can be accomplished through engaging the participant involvement. The teacher has many available techniques: initiate exchanges, create happenings, make declarations and announcements, make requests and assignments, group individuals and direct them to work on a particular activity, invite visitors and volunteers, and so on. In other words, the teacher's task is to create the hustle and bustle of the classroom social and interactive milieu. Thus, by treating students in the classroom as talkers in relationship with one another and the teacher, an actual social situation is set up and talking develops.

In the classroom, the teacher might be concerned about the official characteristics of the talk that takes place there, i.e. correctness, intelligibility, timing and content. Spontaneous talk is not controlled or restricted by such official standards. N. Davis puts emphasis on the fact that while the learners are in spontaneous talk, the teacher's error correction is irrelevant as far as the first priority is developing fluency and spontaneity [5].

Our intention is to share our experience in implementation of role-play in the EFL classroom -a technique which enhances spontaneous talk in the EFL classroom. Let us proceed with some sample activity under the title of Viewpoints where each participant is supposed to express his/ her opinion of the problem.

\section{Role Play \\ TOWORKOR NOT TOWORK, THAT IS THE QUESTION}

Mary Taylor, 35, housewife (physics and maths teacher) would like to go back to teaching, feels unfulfilled at home, has an offer of a job in a nearby school; a friend of hers is a teacher there.

Mark Taylor, 40, Mary's husband, architect, is understanding, does not mind Mary working, has a demanding job, no time or desire to help in the house, feels that Mary might have forgotten a lot about her subjects.

Moira Taylor, 8, Mary's daughter, at school, is afraid her mother will have less time for her when working; would like a brother or sister.

Margaret Taylor, 68, widow. Mark's mother, Mary's mother-in law, runs a bookshop, has been working all her life, supports Mary, lives far away.

Frank and Elizabeth Martin, 70 and 58, Mary's parents, retired postman and housewife, both very much against Mary going back to work, feel both Moira and Mark would suffer, think Mary has everything she needs, live in the next street, come and see their daughter very often.

The above mentioned technique demonstrates how the learner is involved into spontaneous talkin a social situation.

In summary, the pedagogic effort of teaching talk involves exposing the student to social situations in which he is being treated as a talker or a so-

ISSN 2304-7402. Прикарпатський вісник НТШ. Слово. - 2019. - № 3(55). 
cial participant rather than a learner or a participant of a simulated conversation. Through the art of not teaching the language the teacher ensures meaningful interaction in the EFL classroom when learners gain the ability to communicate in the target language.

\section{Лimepamypa}

1. Атанов Г.А. Обгрунтування та сутність діяльнісного підходу до навчання Педагогіка і психологія професійної освіти.2002.№3. С. 85-93.

2. Машбиц Е.И. Психологические основы управления учебной деятельностью. Киев, 1987.

3. Ніколаєва С.Ю. (укладач). Методика навчання іноземних мов у середніх навчальних закладах. Київ, 1999.

4. Arends R.(1991). Learning to teach. New York: McGraw-HillInc.

5. Davies, Norman F. (1982).Training Fluency: Anessentialfactor in language acquisition and use. RELC Journal Vol. 13, 1, P. 1-13.

6. Dewey, J. (1949). Knowing and the known. Boston: Beacon Prentice-Hall.

7. James L.A., Gordon B.V.(1974). The Context of Foreign Language Teaching. Rowley, Mass: Newbury House.

8. Richard-Amato P. (1988). Makingit Happen. Interactioninthe Second Language Classroom. From Theoryto Practice. Longman. N. Y.

9. Richards C.J., Rodgers T.S.(1994). Approaches and Methods in Language Teaching. Cambridge: CUP.

Стаття надійшла до редакиійної колегії 3.04.2019 p. Рекомендовано до друку д.ф.н., професором Аркушиним Г. Л.

\section{НАВЧАННЯ СПОНТАННОГО МОВЛЕННЯ У ПОРІВНЯННІ З ТРАДИЦЙНИМ НАВЧАННЯМ ІНОЗЕМНОЇ МОВИ}

\section{О. М. Серняк}

Тернопільський начиіональний педагогічний університет; 46000, м. Тернопіль, вул. М. Кривоноса, 2; e-mail: oks_sern@ukr.net

У статті проаналізовано аспекти навчання спонтанного іншомовного мовлення у порівнянні з традичійним навчанням іноземної мови, основою якого є накопичення знань про іноземну мову.

Досліджено специфріку іншомовного спонтанного мовлення у процесі вивчення іноземної мови, яка полягає в тому, що студент повинен розглядатися не як учень у класі, а як мовець у іноземному оточенні. Навчання іноземної мови повинно базуватися на навчанні спонтанного мовлення, а не виключно на формуванні знань про іноземну мову.

Роль вчителя іноземної мови визначено у забезпеченні інтерактивної мовленнєвої діяльності студентів на занятті з іноземної мови.

Ключові слова: комунікативний підхід до навчання англійської як іноземної мови, навчання іншомовного спонтанного мовлення, обмін розмовними реплікам,контекстуальна відповідь, обмін повідомленнями.

ISSN 2304-7402. Прикарпатський вісник НТШ. Слово. - 2019. - № 3(55). 